\title{
Article
}

\section{The Effect of Rhizophagus irregularis, Bacillus subtilis and Water Regime on the Plant-Microbial Soil System: The Case of Lactuca sativa}

\author{
Charitini Nikolaidou ${ }^{1}$, Nikolaos Monokrousos ${ }^{2, *(\mathbb{D})}$, Pantelitsa D. Kapagianni ${ }^{1} \mathbb{D}^{\mathbb{D}}$, Michael Orfanoudakis ${ }^{3}$, \\ Triantafyllia Dermitzoglou ${ }^{4}$ and Efimia M. Papatheodorou ${ }^{1, *(D)}$
}

1 Department of Ecology, School of Biology, Aristotle University of Thessaloniki, 54124 Thessaloniki, Greece; char.nikolaidou@gmail.com (C.N.); kapagianni@gmail.com (P.D.K.)

2 University Center of International Programmes of Studies, International Hellenic University, 57001 Thessaloniki, Greece

3 Department of Forestry and Management of the Environment and Natural Resources, Democritus University of Thrace, 68200 Orestiada, Greece; morfan@fmenr.duth.gr

4 R\&D Department of HUMOFERT S.A., 14452 Athens, Greece; fdemi@humofert.gr

* Correspondence: nmonokrousos@ihu.gr (N.M.); papatheo@bio.auth.gr (E.M.P.); Tel.: +30-2310-807572 (N.M.); $+30-2310-998313$ (E.M.P.)

Citation: Nikolaidou, C.; Monokrousos, N.; Kapagianni, P.D.; Orfanoudakis, M.; Dermitzoglou, T.; Papatheodorou, E.M. The Effect of Rhizophagus irregularis, Bacillus subtilis and Water Regime on the Plant-Microbial Soil System: The Case of Lactuca sativa. Agronomy 2021, 11, 2183. https://doi.org/10.3390/ agronomy 11112183

Academic Editor: Nicolas Chemidlin Prevost-Boure

Received: 17 August 2021

Accepted: 25 October 2021

Published: 29 October 2021

Publisher's Note: MDPI stays neutral with regard to jurisdictional claims in published maps and institutional affiliations.

Copyright: (c) 2021 by the authors. Licensee MDPI, Basel, Switzerland. This article is an open access article distributed under the terms and conditions of the Creative Commons Attribution (CC BY) license (https:// creativecommons.org/licenses/by/ $4.0 /)$.

\begin{abstract}
Inoculation with beneficial microbes represents a promising solution for sustainable agricultural production; however, knowledge on the effects of inoculants on the indigenous microbial communities remains limited. Here, we evaluated the impact of the arbuscular mycorrhizal fungus Rhizophagus irregularis and the promoting rhizobacterium Bacillus subtilis on the growth of Lactuca sativa. The biomass, the composition, and the enzyme activity (urease, acid phosphatase, and $\beta$ glycosidase) of the rhizosphere microbial community at two soil moisture levels ( 5 and $10 \%$ soil water content) were evaluated. Fungal colonization was lower in co-inoculated plants than those only inoculated with R. irregularis. Plant growth was enhanced in co-inoculated and B. subtilis inoculated soils. Bacterial biomass and the composition of the microbial communities responded to the joint effect of inoculant type $\times$ water regime while the biomass of the other microbial groups (fungi, actinomycetes, microeukaryotes) was only affected by inoculant type. Co-inoculation enhanced the activity of acid phosphatase, indicating a synergistic effect of the two inoculants. Co-inoculation positively impacted the index reflecting plant-microbial soil functions under both water regimes. We concluded that the interactions between the two inocula as well as between them and the resident rhizosphere microbial community were mainly negative. However, the negative interactions between R. irregularis and $B$. subtilis were not reflected in plant biomass. The knowledge of the plant and rhizosphere microbial responses to single and co-inoculation and their dependency on abiotic conditions is valuable for the construction of synthetic microbial communities that could be used as efficient inocula.
\end{abstract}

Keywords: AMF; enzyme activity; microbial communities; PGPR; plant growth; PLFAs

\section{Introduction}

In recent years, climate change has affected global agricultural production [1], especially in the Mediterranean region, through the increased frequency of seasonal drought events [2]. Drought is one of the greatest natural disasters that affect agricultural productivity [3,4]. Dry conditions affect plant growth directly and indirectly; indirectly through the effect of dryness on the activity and the composition of the rhizosphere microbial communities [5]. Plant health is closely linked to the activity of these microbes and in turn, plants play a key role in determining their community composition [6]. As a result of this close interconnection, changes in the abiotic environment affecting plants are expected to affect the rhizosphere microbiota and vice versa [7]. To increase crop production, the main practices applied include the extensive use of agrochemicals and pesticides [8], which 
can boost plant growth, and suppress pathogenic organisms. However, these products are expensive and toxic to humans and soil health [9], while they cause deleterious side effects on soil beneficial microorganisms that are involved in nutrient cycling processes and biotransformation [10]. There are also environmental concerns about their accumulation in soil [11]. Nevertheless, in recent years, alternative practices that involve the use of microbial inocula consisting of plant growth-promoting rhizobacteria (PGPR) [12], arbuscular mycorrhizal fungi (AMF) [13], or their combination, are gaining ground [14,15]. These are environmentally friendly, enhance plant growth, as well as enable the plant's ability to overcome diseases and mitigate the adverse effects caused by drought.

PGPR plays an important role in the resistance of plants to drought, through the production of phytohormones, osmolytes, exopolysaccharides, the modification of plants' antioxidant defense systems, and the alteration of the host plants' root morphology $[16,17]$. Many Bacillus species that belong to PGPR are widely used for inducing tolerance in water-stressed environments $[18,19]$. In addition, AMF symbiosis enhances plant tolerance through various morphological and physiological mechanisms $[13,20,21]$. The AM fungus species Rhizophagus irregularis is used to mitigate the deleterious effects of drought [22]; it regulates the signaling pathways and the proteins' production involved in plants' responses to drought [23]. However, competitive interactions may occur among inoculants, due to the increased competition for nutrients and/or the production of secondary metabolites that can harm either PGPR or AMF populations [24,25]. These interactions vary between species [26] and under different abiotic conditions. Thus, the best approach to improve plant growth, especially under unfavorable conditions, is to apply the most effective combination of plant species, bacteria, and fungi [27].

Apart from their interactions with plants and between themselves, the introduced microorganisms also exhibit synergistic and/or competitive interactions with the indigenous microbial communities. It was shown that AMF, affected indirectly the growth of rhizosphere microbes, by increasing [28] or reducing roots exudates [29], while PGPR impact on the existing microbial community [30-32] through the production of antibiotics [18]. These complex interactions between plants, microbial inoculants, and indigenous microbial communities are poorly understood and need further clarification, as they could be vital to sustainable agriculture and the mitigation of abiotic stresses.

Over the last years, most studies focused on the beneficial role of PGPR, AMF, and their co-inoculation on plant growth $[18,30,33,34]$. Much of the research in this field was conducted using sterilized soil and therefore only a few studies have analyzed the interactions of these microorganisms with the indigenous soil microbial communities and especially the communities of indigenous bacteria [35-38]. This study aimed to investigate the effect of Bacillus subtilis (PGRB), Rhizophagus irregularis (AM fungus), and their coinoculation on the composition, the structure, and the functions of lettuce (Lactuca sativa L.) rhizosphere microbial community at two soil humidity levels indicative of dry and optimum soil water conditions. Kohler et al. [30] studied the effects of these inoculants separately and jointly on the same plant species measuring plant and soil variables without considering the rhizosphere microbial community; nevertheless, in the present study, we aimed to extend the existing knowledge considering the effects of these inoculants on the indigenous microbial community under different soil water conditions. We hypothesized that the co-inoculation of lettuce plants with these beneficial microorganisms will promote plant growth and improve the plant-microbial soil functions mainly under dry conditions compared to optimum ones since in dry soils the limitations for plant and microbial growth are expected more pronounced.

\section{Materials and Methods}

\subsection{Experimental Design}

The soil that was used for the cultivation of lettuce seeds was collected from an abandoned agricultural area between Lake Koroneia and Volvi, Northern Greece $\left(40.4021^{\circ} \mathrm{N}\right.$, $23.1533^{\circ} \mathrm{E}$ ). The climate of the area is hot-summer Mediterranean (Csa according to Köppen 
Climate Classification) with an average annual precipitation of $554.38 \mathrm{~mm}$ and a mean annual temperature of $15.24^{\circ} \mathrm{C}$. After sampling, the soil was homogenized and passed through a sieve of $6 \mathrm{~mm}$ in order to remove residues of roots or leaves that could alter the soil microbial load. The soil texture was characterized as sandy loam soil (sand: $74 \%$, clay: $6 \%$, silt: $20 \%$ ), and the physicochemical characteristics are presented in Table 1.

Table 1. Physicochemical characteristics of the soil used in our study.

\begin{tabular}{cc}
\hline \multicolumn{1}{c}{ Soil Physicochemical Properties } \\
\hline $\mathrm{pH}$ & 5.72 \\
Electrical conductivity $(\mathrm{mS} / \mathrm{cm})$ & 0.35 \\
Organic $\mathrm{C}(\%)$ & 1.26 \\
$\mathrm{NO}_{3}-\mathrm{N}(\mathrm{mg} / \mathrm{kg})$ & 15.68 \\
$\mathrm{P}(\mathrm{ppm})$ & 20 \\
$\mathrm{~K}(\mathrm{ppm})$ & 125 \\
$\mathrm{Ca}(\mathrm{ppm})$ & 577 \\
$\mathrm{Mg}(\mathrm{ppm})$ & 100 \\
\hline
\end{tabular}

Lactuca sativa seeds were placed in a seed container that was sterilized with ethanol and then filled with sieved soil, and they grew for two months in room temperature conditions. When seedlings reached the stage of five leaves, they were transplanted into $2.5 \mathrm{~L}$ pots that had been previously sterilized with ethanol. During the transplantation, $2 \mathrm{~kg}$ of sieved soil and four seedlings were added to each pot. The seedlings were kept for one week in a soil water content of $10 \%$ (considered sufficient for plant growth [39]) in order to recover from the transplantation stress. After this period, only one seedling per plot remained.

Afterward, plants were inoculated with the rhizobacterium Bacillus subtilis and the AM fungus Rhizophagus irregularis separately or jointly or remained non-inoculated (control). Bacillus subtilis was isolated from the rhizosphere soil of Solanum lycopersicum. The preliminary identification was confirmed by molecular classification with polymerase chain reaction (PCR), using ERIC1f /ERIC2 (ERIC1 5'-ATGTAAGCTCCTGGGGATTCAC3' ERIC2: 5'-AAGTAAGTGACTGGGGTGAGCG-3') oligonucleotide primers, and based on the sequence of $16 \mathrm{~S}$ rDNA gene. The preparation of the inoculum involved the growth of bacteria in nutrient broth $(100 \mathrm{~mL})$ on the rotary shaker for $24-48 \mathrm{~h}$ at $30^{\circ} \mathrm{C}$. Once reached the stationary phase, the cell density of each strain was determined spectrophotometrically (Hitachi U-2800A, Hitachi High-Technologies Corporation, Tokyo, Japan) by comparing the obtained $600 \mathrm{~nm}$ optical densities with the growth calibration curves. After incubation, the bacterial cultures are diluted with $0.85 \% \mathrm{NaCl}$ water solution at the final cell density of about $10^{14-15} \mathrm{CFU} \mathrm{cm}{ }^{-3}$. The Bacillus subtilis inoculant contained $5 \mathrm{~mL}$ of bacterial solution $\left(10^{14-15} \mathrm{CFU} \mathrm{mL}^{-1}\right)$ diluted in $45 \mathrm{~mL}$ of deionized and sterilized water. The AM fungal inoculum consisted of spores and hyphal fragments of $R$. irregularis (BEG 141, 1000 propagules/g-TERI (Energy and Resources Institute, Delhi, India). The viability of the inoculant was tested before the application following the procedure described at Monokrousos et al. [36]. AMF inoculant contained $0.2 \mathrm{~g}$ of powder $\left(10^{6}\right.$ propagules $\left.\mathrm{g}^{-1}\right)$ diluted in $50 \mathrm{~mL}$ of water. The inoculants were injected in the area near the plant roots and left for 4 days without watering to prevent the washout of inoculants. Pots with dual inoculation received $25 \mathrm{~mL}$ of bacterial plus $25 \mathrm{~mL}$ of AM fungal inocula while control pots received $50 \mathrm{~mL}$ of deionized and sterilized water.

In each treatment half of the pots were kept at $5 \% w / w$ soil water content (WC) (dry conditions) throughout the experiment [40], and the rest were kept at 10\% $w / w$ WC (optimum conditions) that impose no limitation to plant growth [39]. Pots were weighed prior to each watering and the amount of added water required was estimated. The experiment lasted for two months (mid-December to mid-February) and took place in a glasshouse at the Aristotle University of Thessaloniki, under natural light conditions with an average temperature of $18^{\circ} \mathrm{C}$. The experimental design included the cultivation of Lactuca sativa 
plants in two water regimes (dry and optimum water conditions) $\times 4$ types of inoculants [Bacillus subtilis inoculant (B), Rhizophagus irregularis inoculant (M), co-inoculation (MB) and without inoculant; control (C)], with four replicates per treatment, giving a total of 32 pots.

After 60 days, a destructive harvest was conducted. Soil samples were collected from the rhizosphere of the plants by shaking the soil that was attached to the roots after the plant's extraction. The rhizosphere soil samples were passed through a $2 \mathrm{~mm}$ sieve and stored at $4{ }^{\circ} \mathrm{C}$ until the end of the analyses (within two weeks after harvest) [41]. Shoots and roots were dried for $48 \mathrm{~h}$ at $70{ }^{\circ} \mathrm{C}$ and weighed. From each pot, at least 50 fresh root fragments $\left(1 \mathrm{~cm}\right.$ length) were stored at $-4{ }^{\circ} \mathrm{C}$ to be used for the determination of the AMF colonization percentage.

\subsection{AMF Colonization}

Root samples were cleaned and stained according to Koske and Gemma [42], modified by Orfanoudakis et al. [43]. The stained samples were examined under a compound microscope (Axio Lab A1, Zeiss, Germany) and AMF root colonization was evaluated according to Trouvelot et al. [44]. The percentage of mycorrhizal colonization was calculated with the MycoCalc software [45].

\subsection{Phospholipid Fatty Acid Analysis}

Microbial communities in soil samples were determined by the phospholipid fatty acids (PLFAs) method as described by Papadopoulou et al. [46]. After the isolation of PLFAs, gas chromatography was performed to determine the chemical compounds present in the samples. A Trace GC Ultra gas chromatograph (ThermoFinnigan, SanJose, CA, USA) was used in conjunction with a Trace ISQ mass spectrometry detector, and a separatorinjector automatic sampler. The chromatographic results were then processed on the XcaliberMS platform to identify the major fatty acids found in the samples. Each fatty acid was measured (in $\mathrm{nmol} \mathrm{g}^{-1}$ ) by a one-point calibration against the GC response of the internal standard (19:0 methyl ester).

A total of 24 phospholipid fatty acids methyl esters were identified in all 32 samples, which are characteristic of specific microbial groups. Given the standard nomenclature that describes phospholipid fatty acids methyl esters, the ones found in our samples are presented in Table 2 [36,47-49]. Biomasses of the microbial groups Gram-positive, Gramnegative, actinomycetes, and microeukaryotes resulted from the sum of the concentration of the fatty acid corresponding to each group of microorganisms, while for fungi biomass all fungal PLFAS were summed except for 16:1w5. Total bacterial biomass resulted from the sum of the fatty acids which are representative of Gram-positive, Gram-negative, and actinomycetes. In addition, ratios such as $\mathrm{Gram}^{+} / \mathrm{Gram}^{-}$and bacteria/fungi which reflect the structure of the soil community were estimated.

Table 2. The phospholipid fatty acids methyl ester biomarkers found in our study.

\begin{tabular}{|c|c|}
\hline \multicolumn{2}{|c|}{ PLFA Biomarkers } \\
\hline i15:0, a15:0, 15:0, i16:0, i17:0, 17:0 & Gram-positive bacteria \\
\hline 16:1w9cis, $16: 1 \omega 9$ trans, cy17:0 & Gram-negative bacteria \\
\hline 10Me16:0, 10Me17:0, 10Me18:0 & Actinomycetes \\
\hline $20: 0,22: 0,24: 0$ & Microeukaryotes \\
\hline $18: 2 \omega 9,12$ & Fungi \\
\hline $18: 1 \omega 9 \mathrm{t}, 18: 1 \omega 9 \mathrm{c}$ & Gram-negative bacteria and fungi \\
\hline $16: 0$ & Bacteria and fungi \\
\hline $11: 0,13: 0,14: 0,18: 0$ & Microbial origin \\
\hline $16: 1 \omega 5$ & AM fungal mycelium \\
\hline
\end{tabular}




\subsection{Enzyme Activity Analysis}

We estimated the enzyme activity of urease, $\beta$-glucosidase (BG), and acid phosphatase (AP) involved in N, C and P-cycles respectively. The activities of AP and BG were determined according to the methodology of Allison and Jastrow [50], modified for 96 well microplates. We used $5 \mathrm{mM}$ p-nitrophenyl-phosphate and $5 \mathrm{mM}$ p-nitrophenyl$\beta$-glucopyranoside solutions for AP and BG, respectively. The p-nitrophenol (pNP) reaction product for AP and BG was measured at $405 \mathrm{~nm}$. The microplate method of Sinsabaugh et al. [51] was used to assess urease activity. The concentration of urea in the assay 96 well microplate was $20 \mathrm{mM}$. The plates were incubated at $20^{\circ} \mathrm{C}$ for $18 \mathrm{~h}$. Ammonium released by the reaction was quantified using colorimetric salicylate and cyanurate reagent packages from Hach (absorbance was measured at $610 \mathrm{~nm}$ by using LT-4500 96-well microplate reader, Labtech, UK).

\subsection{Statistical Analysis}

To determine the effect of water regime, type of microbial inoculant and their interaction on rhizosphere microbial biomasses and their activity, we applied a two-way ANOVA. Prior to analyses, the data were transformed, where necessary, to meet the assumptions of the ANOVA (normal distribution, independence among means and variances, homogeneity of variances). Wherever statistically significant effects were recorded, post hoc comparisons (Fisher LSD) were further applied. To detect changes in microbial community composition between treatments, we applied a one-way analysis of similarities (ANOSIM) based on the Bray-Curtis similarity index (PAST 3 software). Community composition was described by the relevant abundances of individual PLFAs.

Finally, an index that gives an overall picture of the plant-microbial soil functions was estimated separately for each treatment. The higher the value of the index, the better the functionality of the system under consideration [52]. To quantify the index, the zscore of nine variables recorded in each treatment was calculated. The variables were the abundance of Gram-positive, Gram-negative, actinomycetes, fungi, microeukaryotes, the plant dry biomass, and the enzyme activity of AP, BG, and urease. We used the microbial biomasses for the construction of the index because that microbial groups are involved in the biotransformation of recalcitrant (actinomycetes, fungi) and labile substrates (bacteria) and their presence reflects a well-functioning soil. Z-score was calculated for each sample and afterward, the average and standard error of the index for the samples of each treatment were calculated. The effects of water regime, type of microbial inoculant, and their interaction on the index values were determined by a two-way analysis of Variance. All analyses were performed using the SPSS software (version 25).

\section{Results}

\subsection{AMF Colonization}

In relation to humidity level, plants are grown in 5\% WC presented a significantly lower percent of colonization $(p<0.000)$ compared to those growing in $10 \%$ WC. In addition, plants inoculated with fungus and B. subtilis showed a lower colonization percentage than those inoculated only with AM fungus (Table 3).

Table 3. Mean \% colonization ( $\pm \mathrm{SE}$ ) of L. sativa roots by AMF after inoculation with $R$. irregularis or co-inoculation with $R$. irregularis and B. subtilis in dry (5\% WC) and wet (10\% WC) pots. Different superscripts letters denote the differences in \% colonization in relation to the joint effect of water regime $\mathrm{x}$ inoculant type.

\begin{tabular}{ccc}
\hline \multicolumn{3}{c}{ \% AMF Colonization Rate } \\
\hline Inoculant & $5 \%$ WC & $10 \%$ WC \\
\hline R. irregularis & $31.67 \pm 1.67^{\mathrm{b}}$ & $58.80 \pm 1.39^{\mathrm{a}}$ \\
R. irregularis + B. subtilis & $16.40 \pm 0.93^{\mathrm{d}}$ & $22.00 \pm 1.38^{\mathrm{c}}$ \\
\hline
\end{tabular}




\subsection{Plant Growth}

The single effects of water regime and inoculant type on plant growth were significant $(p<0.001$ for both effects) while a non-significant joint effect was recorded. Plants grown at higher WC exhibited significantly higher values of dry biomass than the ones grown at lower WC (Table S1, Figure 1). Moreover, co-inoculated plants (MB) presented significantly higher biomass than the control (C) while B. subtilis and R. irregularis single inoculants had no significant effect on plant growth compared to the control (Table S2).

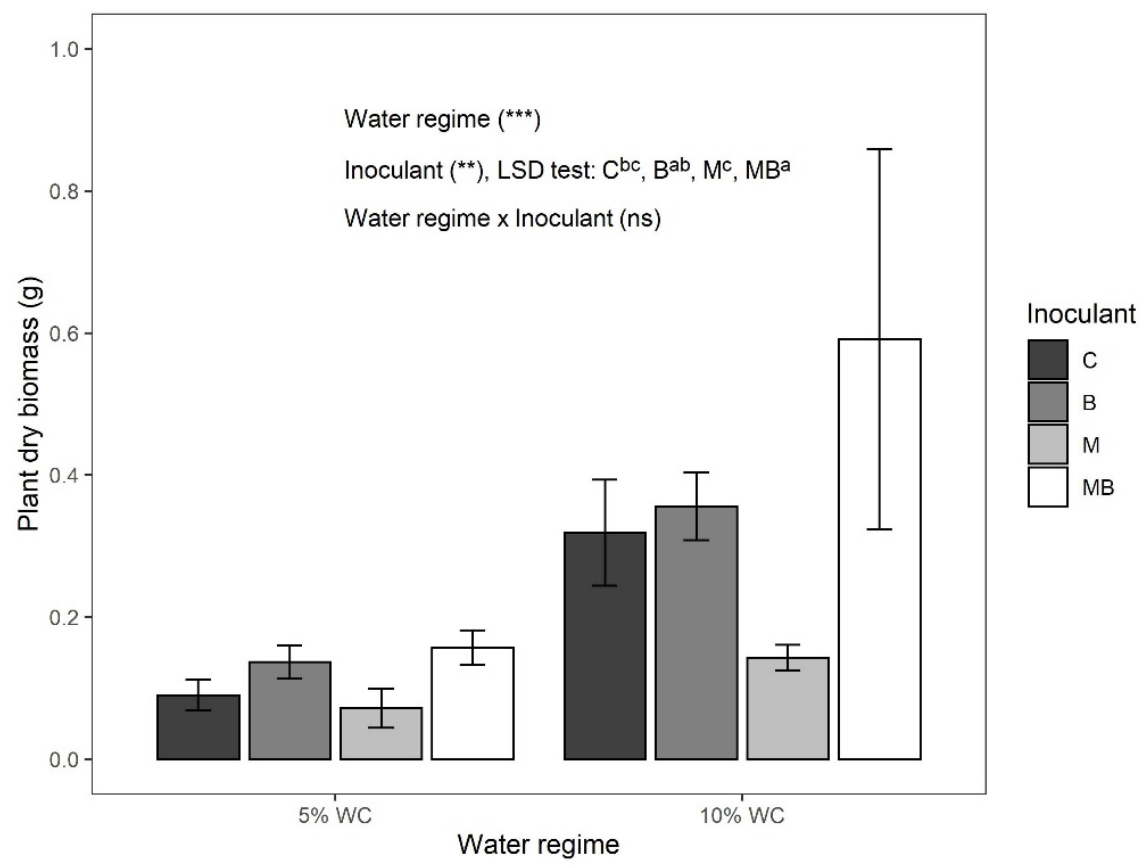

Figure 1. Mean values ( $\pm \mathrm{SE}$ ) of dry biomass (g) of Lactuca sativa plants grown under different water regimes. In the case of significant effects $\left({ }^{* *} p<0.01,{ }^{* * *} p<0.001\right)$, the results of the post hoc comparisons are presented; different superscript letters denote significant differences $(\mathrm{C}=\mathrm{Control}$, $\mathrm{B}=$ B. subtilis, $\mathrm{M}=\mathrm{AMF}, \mathrm{MB}=\mathrm{AMF}$ and B. subtilis).

\subsection{Biomass and Activity of Soil Microbial Community}

The water regime did not affect microbial biomasses, while inoculant type significantly affected the biomass of all microbial groups (Table 4). In addition, the interaction of water regime $\times$ inoculant type significantly affected the biomass of bacteria, $\mathrm{Gram}^{+}(p<0.05)$ and $\mathrm{Gram}^{-}$bacteria $(p<0.001)$ and the bacteria to fungi ratio $(p<0.05)$.

Table 4. Effects of water regime, inoculant type and their interaction on the biomass of individual microbial groups, and the bacteria/fungi and $\mathrm{Gram}^{+} / \mathrm{Gram}^{-}$ratios as revealed by two-way ANOVA ( $\mathrm{n}=4$, df: degree of freedom).

\begin{tabular}{ccccccc}
\hline Microbial Groups & \multicolumn{2}{c}{ Water Regime (1 df) } & \multicolumn{2}{c}{ Inoculant Type (3 df) } & \multicolumn{2}{c}{ Water Regime $\times$ Inoculant Type (3 df) } \\
\hline & F Value & $\boldsymbol{p}$-Value & F Value & $\boldsymbol{p}$ Value & F Value & $p$ Value \\
\hline Bacteria & 6.22 & 0.018 & 8.18 & 0.000 & 3.79 & 0.020 \\
Gram $^{+}$ & 2.09 & 0.158 & 10.64 & 0.000 & 3.90 & 0.000 \\
Gram $^{-}$ & 46.33 & 0.000 & 3.14 & 0.039 & 3.69 & 0.022 \\
Gram $^{+} /$Gram $^{-}$ & 66.56 & 0.000 & 1.63 & 0.202 & 1.72 & 0.183 \\
Bacteria/Fungi & 6.35 & 0.017 & 9.65 & 0.000 & 3.48 & 0.027 \\
Total microbial biomass & 2.60 & 0.116 & 8.03 & 0.000 & 2.03 & 0.129 \\
Fungi & 0.00 & 0.958 & 12.03 & 0.000 & 1.21 & 0.322 \\
Actinomycetes & 0.74 & 0.395 & 7.19 & 0.000 & 2.14 & 0.115 \\
Microeukaryotes & 2.05 & 0.162 & 4.21 & 0.013 & 2.46 & 081 \\
\hline
\end{tabular}


Specifically, the total microbial biomass and the biomass of fungi, actinomycetes, and microeukaryotes exhibited an almost similar pattern of response to inoculant type (Figure 2a,e-g). Higher biomasses were recorded in controls and co-inoculated samples compared to biomasses recorded in rhizosphere soils with single inoculants, while significant differences between the soils inoculated with AM fungus and those with B. subtilis were recorded only in the case of fungi.
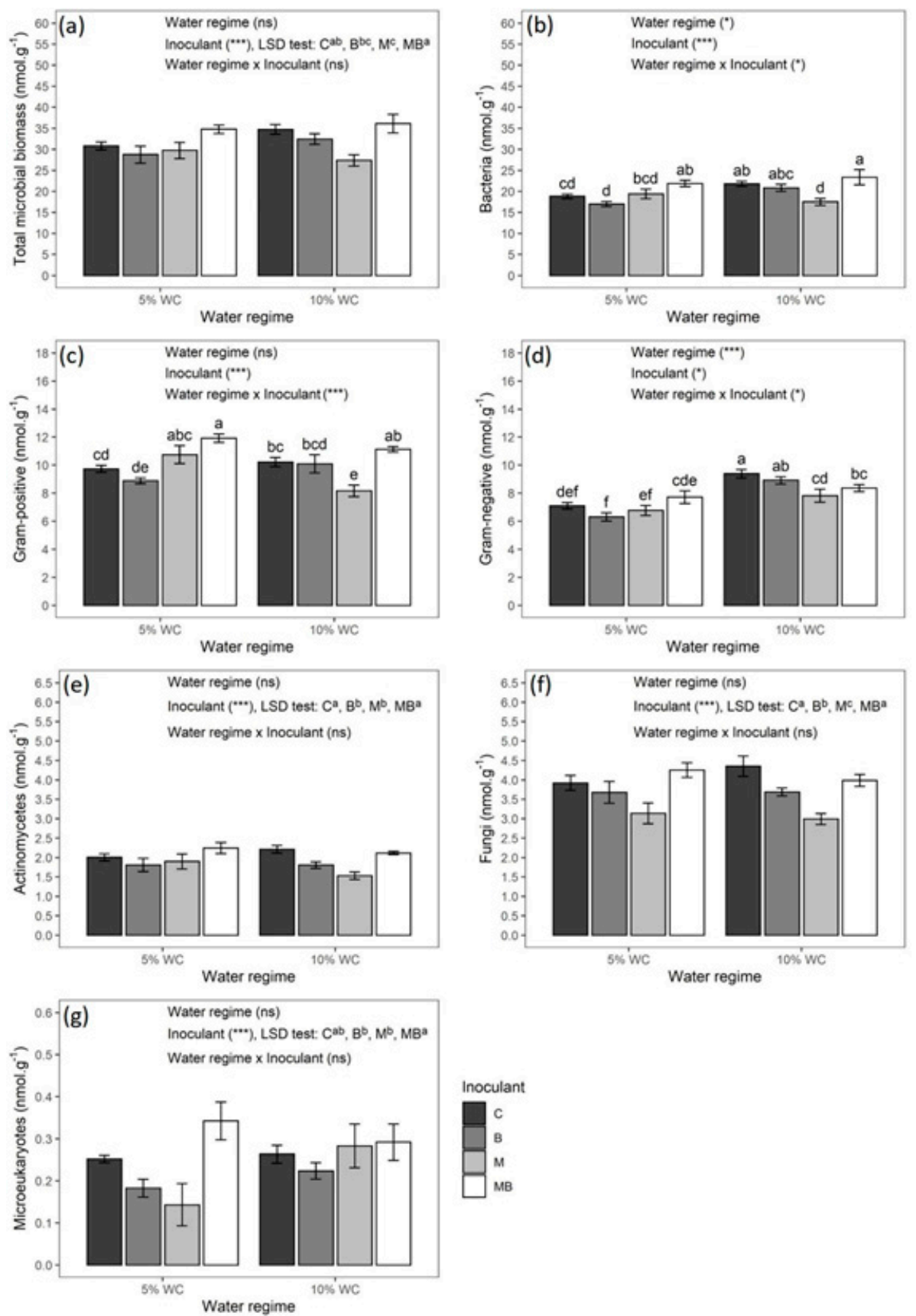

Figure 2. Mean $( \pm \mathrm{SE})$ biomass of total microbes (a), bacteria (b), Gram-positive (c), Gram-negative (d), actinomycetes (e), fungi (f) and microeukaryotes $(\mathbf{g})\left(\mathrm{nmol} \mathrm{g}^{-1}\right)$ in the rhizosphere soil of L. sativa under different water regimes. The significant effect of "inoculant type $\times$ water regime" is presented by the letters above the bars; bars topped by the same letter do not differ significantly. In the case of a single effect of the inoculum type, different superscript letters produced by LSD, denote significant differences (a: corresponds to the highest value, $C=$ Control, $B=B$. subtilis, $M=A M F, M B=A M F$ and B. subtilis). ( ${ }^{*} p<0.05,{ }^{* * *} p<0.001$, ns: non-significant). 
Bacterial biomasses (total biomass as well as that of $\mathrm{Gram}^{+}$and $\mathrm{Gram}^{-}$) showed an idiosyncratic response to the joint effect of the inoculant $x$ water regime. Bacterial biomass was high in co-inoculated soils (no matter the water status), and in controls and B. subtilis soils under optimum water conditions (Figure 2b). The biomass of Gram-positive bacteria was highest in co-inoculated soils in both water regimes and in AMF inoculated dry soils, (Figure 2c). The controls and B. subtilis-inoculated soils under optimum water conditions exhibited the highest biomass of Gram-negative bacteria (Figure 2d).

Changes in the ratios $\mathrm{Gram}^{+} / \mathrm{Gram}^{-}$and bacteria/fungi denote changes in the structure of the microbial community. The $\mathrm{Gram}^{+} / \mathrm{Gram}^{-}$ratio was only significantly influenced by the water regime $(p<0.001$, Table 4$)$. The high $\mathrm{Gram}^{+} / \mathrm{Gram}^{-}$ratio in $5 \% \mathrm{WC}$ (Figure 3a) was mainly caused by a decrease in Gram-negative bacteria, rather than an increase in Gram-positive bacteria, because the biomass of the latter remained constant regardless of the water regime (Table 2). Although fungi were not affected by the water regime, the bacteria/fungi ratio was jointly affected by the inoculant type $\times$ water regime (Table 4). High ratios were reported in AMF-inoculated pots, as well as in co-inoculated and B.subtilis inoculated pots under optimum water conditions (Figure 3b).
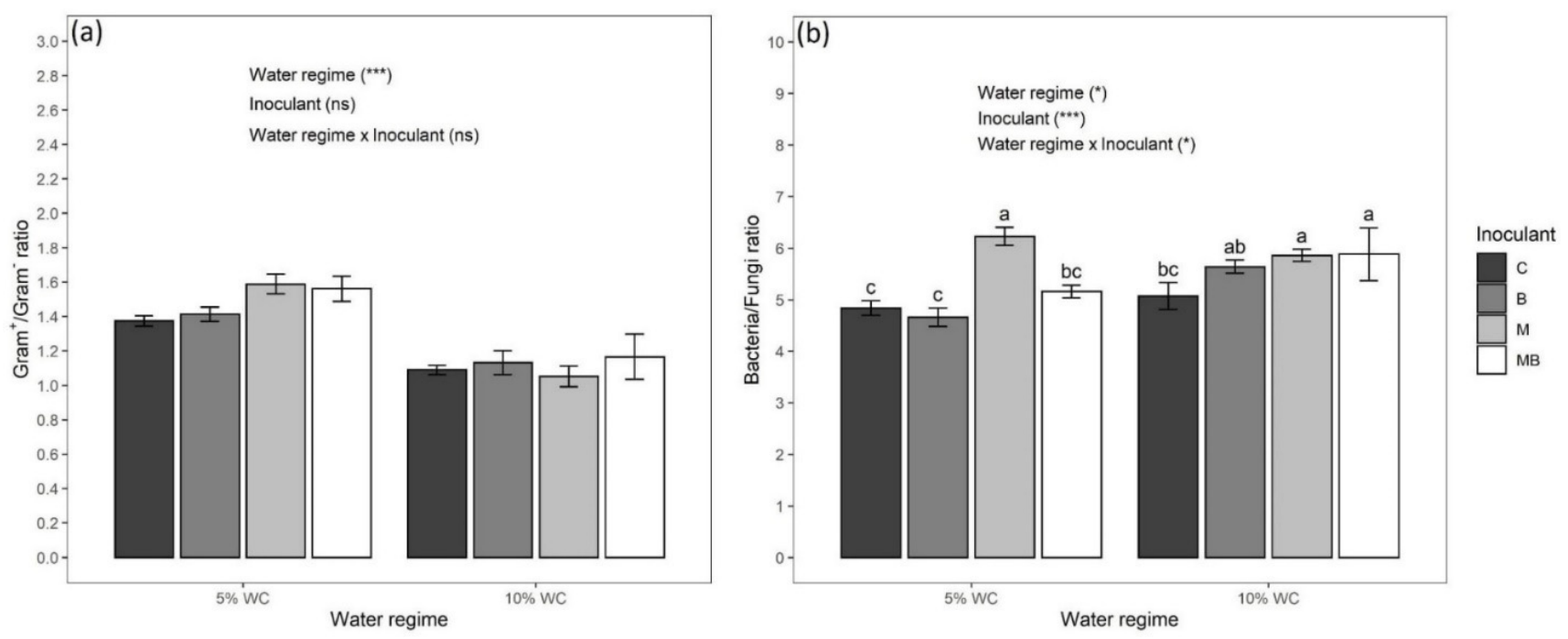

Figure 3. Mean $( \pm \mathrm{SE}) \mathrm{Gram}^{+} / \mathrm{Gram}^{-}(\mathbf{a})$ and bacteria/fungi (b) ratios in soil samples of Lactuca sativa under different water regimes. In the case of significant effects $\left({ }^{*} p<0.05,{ }^{* * *} p<0.001\right)$, the results of the post hoc comparisons are presented. The significant effect of "inoculant type $\times$ water regime" is presented by the letters above the bars; bars topped by the same letter do not differ significantly $(\mathrm{C}=\mathrm{Control}, \mathrm{B}=$ B. subtilis, $\mathrm{M}=\mathrm{AMF}, \mathrm{MB}=\mathrm{AMF}$ and B. subtilis $)$.

Water regime did not significantly affect the activity of any of the three enzymes (Table S3, Figure S1) whereas inoculant type only affected the activity of acid phosphatase. Co-inoculated soils exhibited the highest acid phosphatase activity (Figure 4).

Dissimilarities between treatments as concern the composition of the rhizosphere microbial communities are presented in Table S4. For most cases, no significant differences in composition were revealed. Significant dissimilarities in the composition of the microbial communities were recorded for controls (C: $p=0.047)$, and between the control (C5) and the jointly inoculated soils (MB5) developed at 5\% WC.

\subsection{Index of Plant-Microbial Soil Functions}

The index was significantly affected by the single effect of water regime and inoculant type (Table S5; Figure 5). The z-score values were higher in 10\% WC compared to 5\% while the highest index values were recorded in co-inoculated soils and the lowest in AMF inoculated ones (Figure 5). 


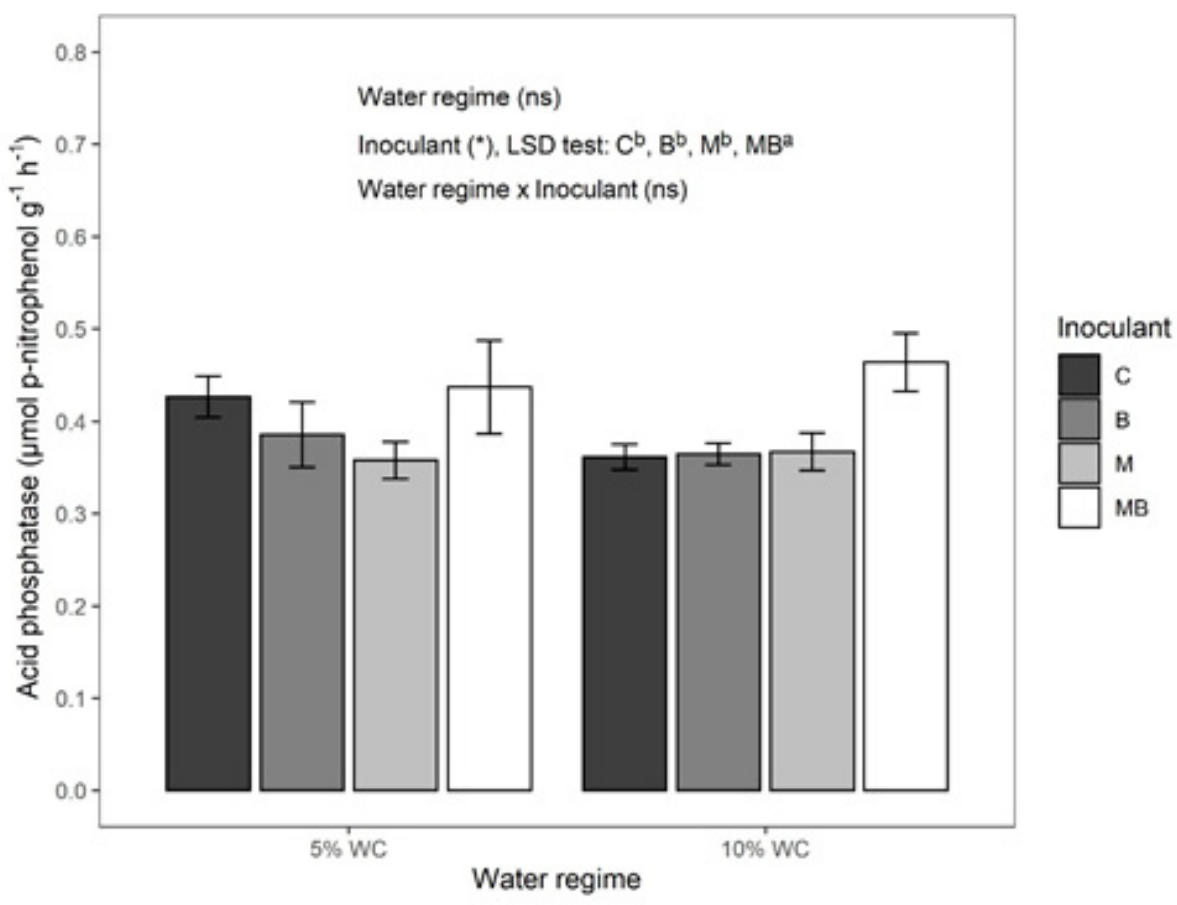

Figure 4. Mean values ( \pm SE) of acid phosphatase activity in rhizosphere soil samples of $L$. sativa under different water regimes. In the case of significant effects $\left({ }^{*} p<0.05\right)$, the results of the post hoc comparisons are presented; different superscript letters denote significant differences $(\mathrm{C}=\mathrm{Control}$, $\mathrm{B}=$ B. subtilis, $\mathrm{M}=\mathrm{AMF}, \mathrm{MB}=\mathrm{AMF}$ and B. subtilis).

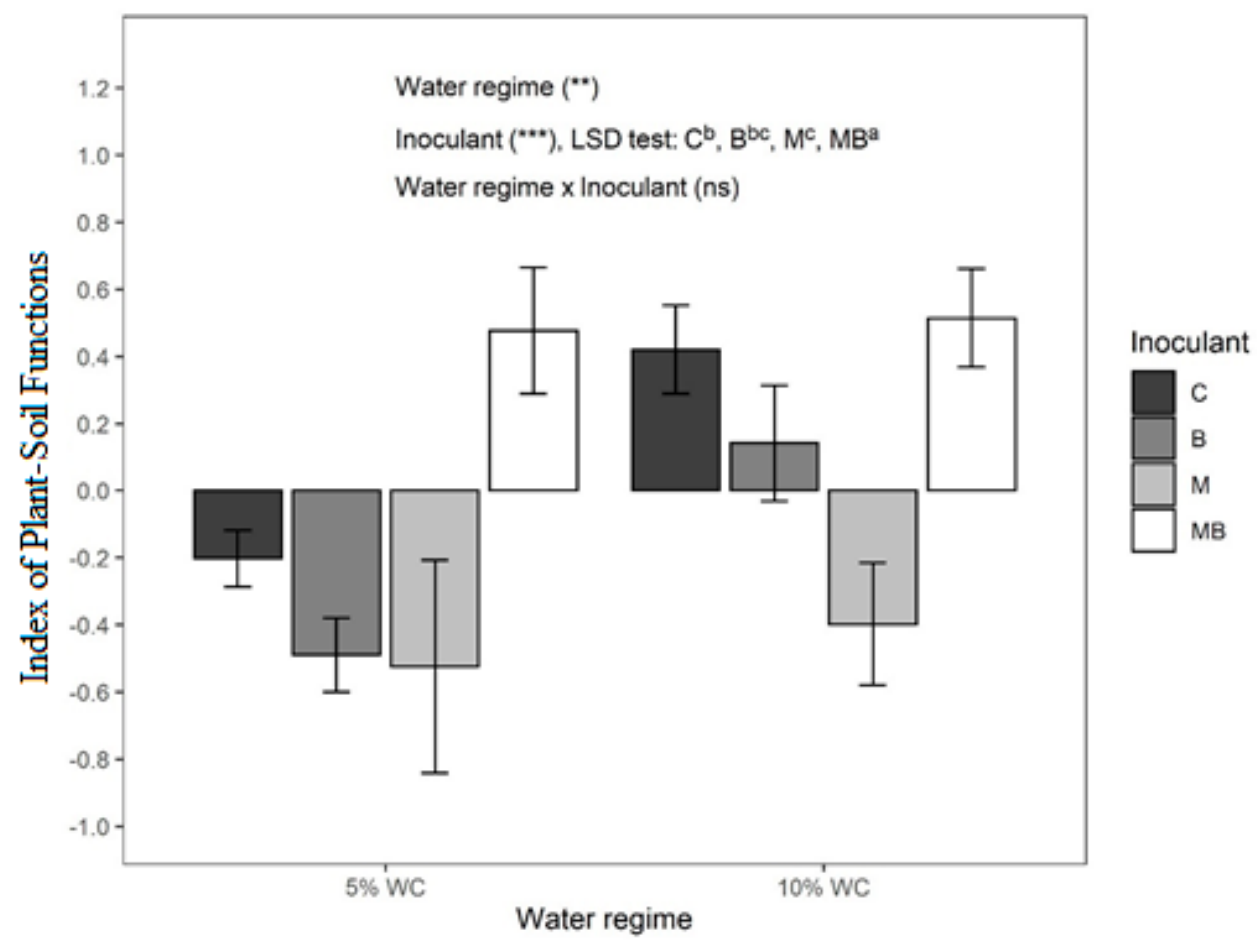

Figure 5. Mean values ( $\pm \mathrm{SE}$ ) of the index of plant-soil interactions obtained from the z-scores of nine variables in soil rhizosphere samples of $L$. sativa under different water regimes. In the case of significant effects $\left({ }^{* *} p<0.01,{ }^{* *} p<0.001\right)$, the results of the post hoc comparisons are presented; different superscript letters denote significant differences $(C=$ Control, $B=B$. subtilis, $M=A M F$, $\mathrm{MB}=\mathrm{AMF}$ and $B$. subtilis). 


\section{Discussion}

The effect of co-inoculation on plant, soil, and rhizosphere microbial traits depends on the inoculants involved and the prevailing abiotic conditions [38,53]. In this study, the effects of water regime and type of microbial inoculants on L. sativa traits and its rhizosphere microbial community were examined. Although there are relevant studies, most of them examined the effect of inoculants on the composition of the rhizosphere bacterial communities at the OTUs level. Herein, an independent effect of water regime and inoculant type for most of the variables were recorded. Dry conditions inhibited the growth of L. sativa and its roots' colonization by AMF. The findings of Saia et al. [54] partially diverse from ours; the reduction in water availability from well- to moderate watered conditions did not affect the lettuce yield but reduced both AMF and Trichoderma presence in the roots and soil. The low soil humidity could impact directly the survival and germination of fungal spores limiting the effectiveness of fungal colonization [23], or indirectly by inhibiting root development [15].

The biomasses of the various microbial groups, the total microbial biomass, and the soil enzyme activity were not affected by the water regime, a fact that implies the tight correlation between biomass and activity. Usually, at low water levels, overall soil microbial biomass decreases [55]. However, microbial biomass could remain stable [56], because of the balance between microbial growth and death [57]. Alternatively, the lack of difference in microbial biomass in dry soils might be explained by the fact that microbial communities originating from dry ecosystems, such as the present system, which was a Mediterranean one, have been adapted to be resilient to long periods of drought [58] since drought is one of the main characteristics of the Mediterranean climate. However, the lack of water effect on total microbial biomass was followed by changes in microbial community structure as indicated by changes in the $\mathrm{Gram}^{+} / \mathrm{Gram}^{-}$ratios. The increased $\mathrm{Gram}^{+} / \mathrm{Gram}^{-}$ ratio under dry conditions was likely due to the reduction in drought-vulnerable Gramnegative bacteria, rather than the increase in Gram-positive ones. Moreover, Fanin et al. [59] mentioned that the $\mathrm{Gram}^{+} / \mathrm{Gram}^{-}$ratio could be used as a coarse indicator of the relative $C$ availability for bacterial communities; it increases with decreasing $C$ availability $[60,61]$. We could assume that the prevailing dry conditions-imposed limitations in decomposition or inhibited $\mathrm{C}$ transfer to bacteria due to water limitation.

Contrary to the response of most microbial biomasses, bacteria are affected significantly by the joint effect of water regime and inoculant type. High values of total bacterial biomass were recorded in optimum watered soils, except those inoculated with $R$. irregularis. This outcome showed that high populations of AM fungus (percentage of colonization $59 \%$ ) could negatively affect the biomass of indigenous bacteria. In both water regimes, the presence of $B$. subtilis inhibited the colonization by R. irregularis, a result that is similar to that reported by Xiao et al. [28]. It is attributed to the ability of B. subtilis strains to synthesize antibiotics with antifungal properties, such as iturin [62].

Similarly to bacterial biomass, the bacteria/fungi ratio of the resident microbial community responded to the joint effect of the two independent variables. In dry soils, the ratio decreased in co-inoculated soils and those inoculated with $B$. subtilis, indicating a shift towards fungal dominance in the presence of $B$. subtilis. This shift in dominance could be indirectly induced by $B$. subtilis; the latter inhibited the growth of AM fungus which acted competitively to the free-living fungi.

\section{Inocula' Effects}

Plants inoculated with $R$. irregularis, exhibited above-ground biomass similar to the control, but lower than that of the co-inoculated or B. subtilis treatments. These differences were similar in both water regimes. The limited ability of $R$. irregularis to enhance plant growth in L. sativa plants was also reported by Kohler et al. [30]. AM fungi do not always form mutualistic relationships with their host plants. Johnson et al. [63] suggested that a commensalistic or, even, parasitic relationship might occur between the two symbionts. The type of relationship is defined by the benefit/cost ratio, which, in turn, is affected by 
developmental, environmental, and genotypic factors [64]. In our case, the cost of maintaining AMF symbiosis seems to be too high for the plant, a fact that imposed limitations on its growth. Kohler et al. [30] also reported that the dual inoculation of L. sativa with Glomus intraradices and B. subtilis promoted plant growth. However, in our study, the plant biomass in co-inoculated soils was similar to that recorded in the B. subtilis inoculated ones. Based on these findings, we assumed that plant growth was enhanced by the presence of $B$. subtilis per se, rather than the presence of both inoculants. The study of Kohler et al. [30] was conducted in more fertile soil than the one used in the current study (available P: 70 vs $15.68 \mu \mathrm{g} \mathrm{g}^{-1}$; available $\mathrm{K}: 440$ vs $125 \mu \mathrm{g} \mathrm{g}^{-1}$ ). In soils with low P and K availability, $B$. subtilis which is phosphate- and potassium-solubilizing rhizobacterium, might enhance mineral uptake by plants by solubilizing insoluble $\mathrm{P}$ and releasing $\mathrm{K}$ from silicate [65], resulting in increased plant growth.

Low rhizosphere microbial biomass was observed in soils inoculated with R. irregularis, or with $B$. subtilis implying the development of negative interactions among the inoculants and the members of the resident microbial community. B. subtilis exerted a negative effect on the biomass of the various microbial groups; fungi and actinomycetes were decreased no matter the water regime while $\mathrm{Gram}^{+}$and $\mathrm{Gram}^{-}$bacteria were decreased in dry soils. In fact, PGPR is characterized by exhibiting highly competitive ability over indigenous microbial communities [10]. Similar to the bacterium, $R$. irregularis reduced the total microbial biomass and the biomass of actinomycetes, microeukaryotes, and fungi (the latter to levels lower than B. subtilis). Competitive interactions between free soil fungi and R. irregularis were documented by Tian et al. [66]. The authors attributed the reduction in fungal abundance to the death of some pathogenic fungi by the development of mycorrhizal mycelium. Alternatively, competition between mycorrhizae and free fungi for nitrogen might exist [67]. Fungal hyphae absorb $\mathrm{NH}_{4}$ and/or $\mathrm{NO}_{3}$ to meet their high nitrogen requirements [68] in order to absorb soil phosphorus. It is also possible that $R$. irregularis by affecting the metabolism of plants induces changes to the profile of root exudates. The inoculation of olive trees with the AM fungi Glomus intraradices followed by the increase in glucose and trechalose and the decrease in fructose, galactose, sucrose, raffinose, and mannitol and by changes in the rhizosphere microbial community; increase in actinomycetes and decrease in bacteria [69].

Co-inoculation resulted in higher than the control plant biomass, but to almost similar to the control, microbial biomasses. The latter could be due to competitive interactions between microbial inoculants during colonization. B. subtilis decreased the ability of the fungus to colonize roots at a percentage of 50\%. However, co-inoculation increased the activity of acid phosphatase, a fact that was in accordance with the results showing that certain bacteria and/or AM fungi secrete phosphatases [70]. According to the microbial resource allocation theory, microbes expend energy to produce enzymes when nutrients are short in supply [71], such as the P-deficient soil environment that existed in this study. Further, the changes in the available soil $\mathrm{P}$ could adjust the establishment of the P-solubilizing strains [38].

Changes in the composition of the resident bacterial communities induced by inocula are usually reported [37,38,72]. For instance, the introduction of Bacillus amyloliquefaciens into soil resulted in the enrichment of two bacterial taxa and the inhibition of other 18 taxa [38] in the cucumber rhizosphere bacterial community. In this study, the analysis of similarities between the microbial communities revealed minor changes in composition because of treatments. Since the water regime had a significant effect only on control pots, it seems that the changes in composition induced by differences in soil water were mitigated by inoculation (single or dual). Also only at 5\% WC, the communities in jointly inoculated pots differed from those in controls, partly supporting our initial hypothesis that differences because of inoculation are expected more pronounced under water-stressed conditions. Similarly, Chao et al. [72] found that the effects of dark septate endophyte inoculation (DSE) on the microbial community composition of licorice rhizosphere soil were dependent on the DSE species and the water regime as well. 


\section{Conclusions}

The interactions between the two inocula as well as between them and the resident rhizosphere microbial community were mainly negative, a fact that could be attributed to the initial low amount of soil nutrients. However, the negative interactions between $R$. irregularis and B. subtilis were not reflected in plant biomass. Co-inoculation improved considerably the functionality of the plant-soil system due to its positive effect on plant growth while the inoculation with the AM fungus deteriorated the index. $R$. irregularis adversely affected plant growth, microbial biomasses, and the enzyme activity in the plant rhizosphere, especially when it occupied a large proportion of the roots. Remarkably, the positive impact of co-inoculation on the index of plant-soil microbial functions was independent of the soil water status, a finding that contradicts our initial hypothesis. The knowledge of the plant and rhizosphere microbial responses to single and co-inoculation and their dependency on abiotic conditions is valuable for the construction of synthetic microbial communities that could be used as efficient inocula.

Supplementary Materials: The following are available online at https://www.mdpi.com/article/10 .3390 /agronomy11112183/s1, Table S1: Effects of water regime, inoculant type and their interaction on dry biomass per plant. Table S2: Effects of water regime, inoculant type and their interaction on soil enzyme activity. Table S3: $p$-values of ANOSIM analysis based on Bray-Curtis index applied on values of individual PLFAs, Figure S1: Mean values $( \pm S E)$ of urease and $\beta$-glucosidase activity in soil samples of L. sativa under different water regimes (5 and 10\% soil water content).

Author Contributions: Conceptualization, E.M.P. and N.M.; formal analysis, C.N. and N.M.; investigation, C.N. and T.D.; methodology, P.D.K., M.O. and T.D.; resources, P.D.K., M.O. and T.D.; supervision, E.M.P.; writing-original draft, C.N.; writing—review and editing, E.M.P., N.M. and P.D.K. All authors have read and agreed to the published version of the manuscript.

Funding: This research received no external funding.

Institutional Review Board Statement: Not applicable.

Informed Consent Statement: Not applicable.

Data Availability Statement: The data presented in this study are available on request from the corresponding authors.

Conflicts of Interest: The authors declare no conflict of interest.

\section{References}

1. Lobell, D.B.; Gourdji, S.M. The influence of climate change on global crop productivity. Plant Physiol. 2012, $160,1686-1697$. [CrossRef]

2. Alamanos, A.; Loukas, A.; Mylopoulos, N.; Xenarios, S.; Vasiliades, L.; Latinopoulos, D. Climate change effects on agriculture in southeast Mediterranean: The case of Karla Watershed in Central Greece. Geophys. Res. Abstr. 2019, $21,1$.

3. Gornall, J.; Betts, R.; Burke, E.; Clark, R.; Camp, J.; Willett, K.; Wiltshire, A. Implications of climate change for agricultural productivity in the early twenty-first century. Philos. Trans. R. Soc. B Biol. Sci. 2010, 365, 2973-2989. [CrossRef]

4. Lesk, C.; Rowhani, P.; Ramankutty, N. Influence of extreme weather disasters on global crop production. Nature 2016, 529, 84-87. [CrossRef]

5. Naylor, D.; Coleman-Derr, D. Drought stress and root-associated bacterial communities. Front. Plant Sci. 2018, 8, 2223. [CrossRef] [PubMed]

6. Berendsen, R.L.; Pieterse, C.M.J.; Bakker, P.A.H.M. The rhizosphere microbiome and plant health. Trends Plant Sci. 2012, 17, 478-486. [CrossRef] [PubMed]

7. Wardle, D.A.; Bardgett, R.D.; Klironomos, J.N.; Setälä, H.; Van Der Putten, W.H.; Wall, D.H. Ecological linkages between aboveground and belowground biota. Science 2004, 304, 1629-1633. [CrossRef]

8. Goswami, D.; Thakker, J.N.; Dhandhukia, P.C. Portraying mechanics of plant growth promoting rhizobacteria (PGPR): A review. Cogent Food Agric. 2016, 2, 1127500. [CrossRef]

9. Dodd, I.C.; Belimov, A.A.; Sobeih, W.Y.; Safronova, V.I.; Grierson, D.; Davies, W.J. Will modifying plant ethylene status improve plant productivity in water-limited environments. In Proceedings of the 4th International Crop Science Congress, Brisbane, Australia, 26 September-1 October 2004; p. 134.

10. Mandal, A.; Sarkar, B.; Mandal, S.; Vithanage, M.; Patra, A.K.; Manna, M.C. Impact of Agrochemicals on Soil Health. In Agrichemicals Detection, Treatment and Remediation; Butterworth-Heinemann: Oxford, UK, 2020; pp. 161-187. ISBN 9780081030172. 
11. Silva, V.; Mol, H.G.J.; Zomer, P.; Tienstra, M.; Ritsema, C.J.; Geissen, V. Pesticide residues in European agricultural soils-A hidden reality unfolded. Sci. Total Environ. 2019, 653, 1532-1545. [CrossRef]

12. Glick, B.R. Bacteria with ACC deaminase can promote plant growth and help to feed the world. Microbiol. Res. 2014, 169, 30-39. [CrossRef] [PubMed]

13. Lenoir, I.; Fontaine, J.; Lounès-Hadj Sahraoui, A. Arbuscular mycorrhizal fungal responses to abiotic stresses: A review. Phytochemistry 2016, 123, 4-15. [CrossRef]

14. Nadeem, S.M.; Ahmad, M.; Zahir, Z.A.; Javaid, A.; Ashraf, M. The role of mycorrhizae and plant growth promoting rhizobacteria (PGPR) in improving crop productivity under stressful environments. Biotechnol. Adv. 2014, 32, 429-448. [CrossRef]

15. Karthikeyan, B.; Abitha, B.; Henry, A.J.; Sa, T.; Joe, M.M. Interaction of rhizobacteria with arbuscularmycorrhizal fungi (AMF) and their role in stress abetment in agriculture. In Recent Advances on Mycorrhizal Fungi; Springer: Cham, Switzerland, 2016; pp. 117-142. ISBN 978-3-319-24353-5.

16. Ngumbi, E.; Kloepper, J. Bacterial-mediated drought tolerance: Current and future prospects. Appl. Soil Ecol. 2016, 105, 109-125. [CrossRef]

17. Vurukonda, S.S.K.P.; Vardharajula, S.; Shrivastava, M.; SkZ, A. Enhancement of drought stress tolerance in crops by plant growth promoting rhizobacteria. Microbiol. Res. 2016, 184, 13-24. [CrossRef] [PubMed]

18. Hashem, A.; Tabassum, B.; Fathi Abd_Allah, E. Bacillus subtilis: A plant-growth promoting rhizobacterium that also impacts biotic stress. Saudi J. Biol. Sci. 2019, 26, 1291-1297. [CrossRef]

19. Gagné-Bourque, F.; Mayer, B.F.; Charron, J.B.; Vali, H.; Bertrand, A.; Jabaji, S. Accelerated growth rate and increased drought stress resilience of the model grass brachypodium distachyon colonized by bacillus subtilis B26. PLoS ONE 2015, 10, e0130456. [CrossRef]

20. Wu, Q.S.; Zou, Y.N. Arbuscular Mycorrhizal Fungi and Tolerance of Drought Stress in Plants. In Arbuscular Mycorrhizas and Stress Tolerance of Plants; Springer: Singapore, 2017; pp. 25-41. ISBN 9789811041150.

21. Wu, Q.S.; Srivastava, A.K.; Zou, Y.N. AMF-induced tolerance to drought stress in citrus: A review. Sci. Hortic. 2013, 164, 77-87. [CrossRef]

22. Li, T.; Lin, G.; Zhang, X.; Chen, Y.; Zhang, S.; Chen, B. Relative importance of an arbuscular mycorrhizal fungus (Rhizophagus intraradices) and root hairs in plant drought tolerance. Mycorrhiza 2014, 24, 595-602. [CrossRef] [PubMed]

23. Porcel, R.; Aroca, R.; Cano, C.; Bago, A.; Ruiz-Lozano, J.M. Identification of a gene from the arbuscular mycorrhizal fungus Glomus intraradices encoding for a 14-3-3 protein that is up-regulated by drought stress during the AM symbiosis. Microb. Ecol. 2006, 52, 575-582. [CrossRef]

24. Xiao, X.; Chen, H.; Chen, H.; Wang, J.; Ren, C.; Wu, L. Impact of Bacillus subtilis JA, a biocontrol strain of fungal plant pathogens, on arbuscular mycorrhiza formation in Zea mays. World J. Microbiol. Biotechnol. 2008, 24, 1133-1137. [CrossRef]

25. Trivedi, P.; Pandey, A.; Palni, L.M.S. Bacterial inoculants for field applications under mountain ecosystem: Present initiatives and future prospects. In Bacteria in Agrobiology: Plant Probiotics; Springer: Berlin/Heidelberg, Germany, 2012; pp. 15-44. ISBN 9783642275159 .

26. Jäderlund, L.; Arthurson, V.; Granhall, U.; Jansson, J.K. Specific interactions between arbuscular mycorrhizal fungi and plant growth-promoting bacteria: As revealed by different combinations. FEMS Microbiol. Lett. 2008, 287, 174-180. [CrossRef] [PubMed]

27. Larsen, J.; Cornejo, P.; Barea, J.M. Interactions between the arbuscular mycorrhizal fungus Glomus intraradices and the plant growth promoting rhizobacteria Paenibacillus polymyxa and P. macerans in the mycorrhizosphere of Cucumis sativus. Soil Biol. Biochem. 2009, 41, 286-292. [CrossRef]

28. Azaizeh, H.A.; Marschner, H.; Römheld, V.; Wittenmayer, L. Effects of a vesicular-arbuscular mycorrhizal fungus and other soil microorganisms on growth, mineral nutrient acquisition and root exudation of soil-grown maize plants. Mycorrhiza 1995, 5, 321-327. [CrossRef]

29. Gupta Sood, S. Chemotactic response of plant-growth-promoting bacteria towards roots of vesicular-arbuscular mycorrhizal tomato plants. FEMS Microbiol. Ecol. 2003, 45, 219-227. [CrossRef]

30. Kohler, J.; Caravaca, F.; Carrasco, L.; Roldán, A. Interactions between a plant growth-promoting rhizobacterium, an AM fungus and a phosphate-solubilising fungus in the rhizosphere of Lactuca sativa. Appl. Soil Ecol. 2007, 35, 480-487. [CrossRef]

31. Ramos, B.; García, J.A.L.; Probanza, A.; Barrientos, M.L.; Gutierrez Mañero, F.J. Alterations in the rhizobacterial community associated with European alder growth when inoculated with PGPR strain Bacillus licheniformis. Environ. Exp. Bot. 2003, 49, 61-68. [CrossRef]

32. Jha, C.K.; Saraf, M. Plant growth promoting Rhizobacteria (PGPR): A review. J. Agric. Res. Dev. 2015, 5, 108-119. [CrossRef]

33. Adesemoye, A.O.; Torbert, H.A.; Kloepper, J.W. Enhanced plant nutrient use efficiency with PGPR and AMF in an integrated nutrient management system. Can. J. Microbiol. 2008, 54, 876-886. [CrossRef]

34. Subramanian, K.S.; Santhanakrishnan, P.; Balasubramanian, P. Responses of field grown tomato plants to arbuscular mycorrhizal fungal colonization under varying intensities of drought stress. Sci. Hortic. 2006, 107, 245-253. [CrossRef]

35. Malviya, M.K.; Sharma, A.; Pandey, A.; Rinu, K.; Sati, P.; Palni, L.M.S. Bacillus subtilis NRRL B-30408: A potential inoculant for crops grown under rainfed conditions in the mountains. J. Soil Sci. Plant Nutr. 2012, 12, 811-824. [CrossRef]

36. Monokrousos, N.; Papatheodorou, E.M.; Orfanoudakis, M.; Jones, D.G.; Scullion, J.; Stamou, G.P. The effects of plant type, AMF inoculation and water regime on rhizosphere microbial communities. Eur. J. Soil Sci. 2020, 71, 265-278. [CrossRef] 
37. Sakineh, A.; Ayme, S.; Akram, S.; Safaie, N. Streptomyces strains modulate dynamics of soil bacterial communities and their efficacy in disease suppression caused by Phytophthora capsici. Sci. Rep. 2021, 11, 9317.

38. Wang, J.; Xu, S.; Yang, R.; Zhao, W.; Zhu, D.; Zhang, X.; Huang, Z. Bacillus amyloliquefaciens FH-1 significantly affects cucumber seedlings and the rhizosphere bacterial community but not soil. Sci. Rep. 2021, 11, 12055. [CrossRef] [PubMed]

39. Troelstra, S.R.; Wagenaar, R.; Smant, W.; Peters, B.A.M. Interpretation of bioassays in the study of interactions between soil organisms and plants: Involvement of nutrient factors. New Phytol. 2001, 150, 697-706. [CrossRef]

40. Ratnayaka, D.D.; Brandt, M.J.; Johnson, K.M. Hydrology and Surface Supplies. In Water Supply; Butterworth-Heinemann: Oxford, UK, 2009; pp. 63-107. ISBN 978-0-7506-6843-9.

41. Carter, M.R.; Gerard, G. Soil Sampling and Methods of Analysis; CRC Press: Boca Raton, FL, USA, 2007.

42. Koske, R.E.; Gemma, J.N. A modified procedure for staining roots to detect VA mycorrhizas. Mycol. Res. 1989, 92, 486-488. [CrossRef]

43. Orfanoudakis, M.; Wheeler, C.T.; Hooker, J.E. Both the arbuscular mycorrhizal fungus Gigaspora rosea and Frankia increase root system branching and reduce root hair frequency in Alnus glutinosa. Mycorrhiza 2010, 20, 117-126. [CrossRef] [PubMed]

44. Trouvelot, A.; Kough, J.L.; Gianinazzi-pearson, V. Mesure du taux de mycorhization VA d'un systeme radiculaire. Recherche de methodes d'estimation ayant une signification fonctionnelle. In Physiological and Genetical Aspects of Mycorrhizae: Proceedings of the 1st European Symposium on Mycorrhizae, Dijon, 1-5 July 1985; Gianinazzi, S., Gianinazzi-Pearson, V., Eds.; Institut National de la Recherche Agronomique, INRA: Paris, French, 1986; pp. 217-221.

45. Available online: http://www2.dijon.inra.fr/mychintec/Mycocalc-prg/download.html (accessed on 20 March 2019).

46. Papadopoulou, E.S.; Karpouzas, D.G.; Menkissoglu-Spiroudi, U. Extraction parameters significantly influence and the quantity and the profile of PLFAs extracted from soil. Microb. Ecol. 2011, 62, 704-714. [CrossRef]

47. Ntalli, N.; Monokrousos, N.; Rumbos, C.; Kontea, D.; Zioga, D.; Argyropoulou, M.D.; Menkissoglu-Spiroudi, U.; Tsiropoulos, N.G. Greenhouse biofumigation with Melia azedarach controls Meloidogyne spp. and enhances soil biological activity. J. Pest Sci. 2018, 91, 29-40. [CrossRef]

48. Stamou, G.; Konstadinou, S.; Monokrousos, N.; Mastrogianni, A.; Orfanoudakis, M.; Hassiotis, C.; Menkissoglu-Spiroudi, U.; Vokou, D.; Papatheodorou, E.M. The effects of arbuscular mycorrhizal fungi and essential oil on soil microbial community and N-related enzymes during the fungal early colonization phase. AIMS Microbiol. 2017, 3, 938-959. [CrossRef]

49. Olsson, P.A. Signature fatty acids provide tools for determination of the distribution and interactions of mycorrhizal fungi in soil. FEMS Microb. Ecol. 2006, 29, 303-310. [CrossRef]

50. Allison, S.D.; Jastrow, J.D. Activities of extracellular enzymes in physically isolated fractions of restored grassland soils. Soil Biol. Biochem. 2006, 38, 3245-3256. [CrossRef]

51. Sinsabaugh, R.L.; Reynolds, H.; Long, T.M. Rapid assay for amidohydrolase (urease) activity in environmental samples. Soil Biol. Biochem. 2000, 32, 2095-2097. [CrossRef]

52. Maestre, F.T.; Quero, J.L.; Gotelli, N.J.; Escudero, A.; Ochoa, V.; Delgado-Baquerizo, M.; García-Gómez, M.; Bowker, M.A.; Soliveres, S.; Escolar, C.; et al. Plant species richness and ecosystem multifunctionality in global drylands. Science 2012, 335, 214-218. [CrossRef]

53. Ambrosini, A.; de Souza, R.; Passaglia, L.M.P. Ecological role of bacterial inoculants and their potential impact on soil microbial diversity. Plant Soil 2016, 400, 193-207. [CrossRef]

54. Saia, S.; Colla, G.; Raimondi, G.; Di Stasio, E.; Cardarelli, M.; Bonini, P.; Vitaglione, P.; De Pascale, S.; Rouphael, Y. An endophytic fungi-based biostimulant modulated lettuce yield, physiological and functional quality responses to both moderate and severe water limitation. Sci. Hortic. 2019, 256, 108595. [CrossRef]

55. Hueso, S.; García, C.; Hernández, T. Severe drought conditions modify the microbial community structure, size and activity in amended and unamended soils. Soil Biol. Biochem. 2012, 50, 167-173. [CrossRef]

56. Hartmann, M.; Brunner, I.; Hagedorn, F.; Bardgett, R.D.; Stierli, B.; Herzog, C.; Chen, X.; Zingg, A.; Graf-Pannatier, E.; Rigling, A.; et al. A decade of irrigation transforms the soil microbiome of a semi-arid pine forest. Mol. Ecol. 2017, 26, 1190-1206. [CrossRef]

57. Schimel, J.P. Life in Dry Soils: Effects of Drought on Soil Microbial Communities and Processes. Annu. Rev. Ecol. Evol. Syst. 2018, 49, 409-432. [CrossRef]

58. Landesman, W.J.; Dighton, J. Response of soil microbial communities and the production of plant-available nitrogen to a two-year rainfall manipulation in the New Jersey Pinelands. Soil Biol. Biochem. 2010, 42, 1751-1758. [CrossRef]

59. Fanin, N.; Kardol, P.; Farrell, M.; Nilsson, M.-C.; Gundale, M.J.; Wardle, D.A. The ratio of Gram-positive to Gram-negative bacterial PLFA markers as an indicator of carbon availability in organic soils. Soil Biol. Biochem. 2019, 128, 111-114. [CrossRef]

60. Fierer, N.; Schimel, J.P.; Holden, P.A. Variations in microbial community composition through two soil depth profiles. Soil Biol. Biochem. 2003, 35, 167-176. [CrossRef]

61. Breulmann, M.; Masyutenko, N.P.; Kogut, B.M.; Schroll, R.; Dorfler, U.; Buscot, F.; Schulz, E. Short-term bioavailability of carbon in soil organic matter fractions of different particle sizes and densities in grassland ecosystems. Sci. Total Environ. 2014, 497-498. [CrossRef]

62. Citernesi, A.S.; Filippi, C.; Bagnoli, G.; Giovannetti, M. Effects of the antimycotic molecule Iturin A2, secreted by Bacillus subtilis strain M51, on arbuscular mycorrhizal fungi. Microbiol. Res. 1994, 149, 241-246. [CrossRef] 
63. Johnson, N.C.; Graham, J.H.; Smith, F.A. Functioning of mycorrhizal associations along the mutualism-parasitism continuum. New Phytol. 1997, 135, 575-585. [CrossRef]

64. Janos, D.P. Plant responsiveness to mycorrhizas differs from dependence upon mycorrhizas. Mycorrhiza. 2007, 442, 75-91. [CrossRef] [PubMed]

65. Toro, M.; Azcón, R.; Barea, J.M. Improvement of arbuscular mycorrhiza development by inoculation of soil with phosphatesolubilizing rhizobacteria to improve rock phosphate bioavailability (32P) and nutrient cycling. Appl. Environ. Microbiol. 1997, 63, 4408-4412. [CrossRef] [PubMed]

66. Tian, L.; Shi, S.; Ma, L.; Zhou, X.; Luo, S.; Zhang, J.; Lu, B.; Tian, C. The effect of Glomus intraradices on the physiological properties of Panax ginseng and on rhizospheric microbial diversity. J. Ginseng Res. 2019, 43, 77-85. [CrossRef]

67. Konstantinou, S.; Monokrousos, N.; Kapagianni, P.; Menkissoglu-Spiroudi, U.; Gwynn-Jones, D.; Stamou, G.P.; Papatheodorou, E.M. Instantaneous responses of microbial communities to stress in soils pretreated with Mentha spicata essential oil and/or inoculated with arbuscular mycorrhizal fungus. Ecol. Res. 2019, 34, 701-710. [CrossRef]

68. Hodge, A.; Fitter, A.H. Substantial nitrogen acquisition by arbuscular mycorrhizal fungi from organic material has implications for N cycling. Proc. Natl. Acad. Sci. USA 2010, 107, 13754-13759. [CrossRef]

69. Mechri, B.; Manga, A.G.B.; Tekaya, M.; Attia, F.; Cheheb, H.; Meriem, F.B.; Braham, M.; Boujnah, D.; Hammami, M. Changes in microbial communities and carbohydrate profiles induced by the mycorrhizal fungus (Glomus intraradices) in rhizosphere of olive trees (Olea europaea L.). Appl. Soil Ecol. 2014, 75, 124-133. [CrossRef]

70. Kim, Y.; Jordan, D.; McDonald, G.A. Effect of phosphate-solubilizing bacteria and vesicular-arbuscular mycorrhizae on tomato growth and soil microbial activity. Biol. Fertil. Soils 1997, 26, 79-87. [CrossRef]

71. Stone, M.M.; Plante, A.F.; Casper, B.B. Plant and nutrient controls on microbial functional characteristics in a tropical Oxisol. Plant Soil 2013, 373, 893-905. [CrossRef]

72. He, C.; Wang, W.; Hou, J. Plant growth and soil microbial impacts of enhancing licorice with inoculating dark septate endophytes under drought stress. Front. Microbiol. 2019, 10, 2277. [CrossRef] [PubMed] 